\title{
EFFECT OF THE AUSTEMPERING PROCESS ON THE MICROSTRUCTURE AND MECHANICAL PROPERTIES OF 27MnCrB5-2 STEEL
}

\begin{abstract}
The effect of austempering parameters on the microstructure and mechanical properties of 27MnCrB5-2 steel has been investigated by means of: dilatometric, microstructural and fractographic analyses; tensile and Charpy V-notch $(\mathrm{CVN})$ impact tests at room temperature and a low temperature.

Microstructural analyses showed that upper bainite developed at a higher austempering temperature, while a mixed bainiticmartensitic microstructure formed at lower temperatures, with a different amount of bainite and martensite and a different size of bainite sheaf depending on the temperature. Tensile tests highlighted superior yield and tensile strengths $(\approx 30 \%)$ for the mixed microstructure, with respect to both fully bainitic and Q\&T microstructures, with only a low reduction in elongation to failure $(\approx 10 \%)$. Impact tests confirmed that mixed microstructures have higher impact properties, at both room temperature and a low temperature.

Keywords: 27MnCrB5-2, austempering, microstructure, mechanical properties, low temperature
\end{abstract}

\section{Introduction}

Boron alloyed Q\&T steels have good hardness, wear resistance, high strength and good toughness and are widely employed for manufacturing mechanical engineering components, such as dredger buckets, plough shares, chain wheels and axles.

Their strength and impact toughness could be further improved by replacing conventional Q\&T with austempering, which leads to bainitic or mixed bainite-martensite microstructures $[1,2]$.

The strength of a fully bainitic microstructure is the result of the synergic effect of: (i) yield strength of pure iron; (ii) solid solution hardening, depending on chemical composition; (iii) precipitation hardening related to the morphology and density of precipitates; (iv) forest dislocations and grain size strengthening, due to grain size and grain boundary misorientation [3].

Several studies reported that the presence of a microstructure of lower bainite and martenisite provides a better combination of mechanical properties (especially strength and toughness), compared to both upper and lower bainite and mixed upper bainite-martensite $[1,4,5]$.

The presence of small packets, induced by the simultaneous presence of martensite and lower bainite, increase the density of high angle boundaries that hinders crack propagation, while the finer carbide size increases the precipitation hardening effect $[6,7]$.

The objective of this study is to compare the effect of upper bainitic microstructures and mixed lower bainite-martensite microstructures, with different amounts of martensite, on strength, ductility and impact toughness of the EN-27MnCrB5-2 steel.

\section{Experimental}

Commercially available Q\&T EN-27MnCrB5 steel bars (composition reported in Table 1) with a diameter of $25 \mathrm{~mm}$ were used for the production of samples for dilatometric analysis, heat treatment tests, microstructural and mechanical characterization.

Dilatometric analyses were carried out by means of a Bähr 805A/D dilatometer to determine the steel transformation temperatures and the critical cooling rate, i.e., the minimum rate to avoid perlitic transformation during austempering. Cylindrical samples (4 $\mathrm{mm}$ diameter, $10 \mathrm{~mm}$ length) were extracted from the bars along the longitudinal direction.

Chemical composition (wt\%) of the EN-27MnCrB5

\begin{tabular}{|c|c|c|c|c|c|c|c|c|c|c|}
\hline \hline $\mathbf{C}$ & $\mathbf{M n}$ & $\mathbf{S i}$ & $\mathbf{S}$ & $\mathbf{P}$ & $\mathbf{C r}$ & $\mathbf{C u}$ & $\mathbf{A l}$ & $\mathbf{T i}$ & $\mathbf{B}$ & $\mathbf{F e}$ \\
\hline 0.2790 & 1.2940 & 0.2770 & 0.0020 & 0.0070 & 0.3790 & 0.2250 & 0.0190 & 0.0470 & 0.0023 & Bal. \\
\hline
\end{tabular}

\footnotetext{
* DEPARTMENT OF INDUSTRIAL ENGINEERING - UNIVERSITY OF BOLOGNA, ITALY 
According to the TTT curves, obtained by means of dilatometric analysis, specimens with a $13 \mathrm{~mm}$ diameter and $100 \mathrm{~mm}$ length were austenitized at $840^{\circ} \mathrm{C}$ (A series) and $940^{\circ} \mathrm{C}$ (B series) for 20 and $40 \mathrm{~min}$ and directly quenched in a salt bath between $240^{\circ} \mathrm{C}$ and $400^{\circ} \mathrm{C}$ for different holding times. The parameters of the austempering cycles are summarized in Table 2.

TABLE 2

Austempering parameters. The salt bath temperatures and holding times are confidential data and have been reported as ranges. $\mathrm{H}=$ High temperature $\left(\mathrm{T}>380^{\circ} \mathrm{C}\right), \mathrm{M}=$ Medium temperature $\left(340<\mathrm{T}<380^{\circ} \mathrm{C}\right), \mathrm{L}=$ Low temperature $\left(300<\mathrm{T}<340^{\circ} \mathrm{C}\right)$, $\mathrm{VL}=$ Very low temperature $\left(\mathrm{T}<300^{\circ} \mathrm{C}\right), \mathrm{t} 1<30 \mathrm{~min}$ and $\mathrm{t} 2>30 \mathrm{~min}$

\begin{tabular}{|c|c|c|c|c|}
\hline $\begin{array}{c}\text { Heat } \\
\text { Treatment } \\
\text { cycle }\end{array}$ & $\begin{array}{c}\text { Austenitization } \\
\text { temperature } \\
{\left[{ }^{\circ} \mathbf{C}\right]}\end{array}$ & $\begin{array}{c}\text { Austenitization } \\
\text { time } \\
{[\mathbf{m i n}]}\end{array}$ & $\begin{array}{c}\text { Austempering } \\
\text { temperature }\end{array}$ & $\begin{array}{c}\text { Holding } \\
\text { time }\end{array}$ \\
\hline AH-1 & 840 & 20 & High & $\mathrm{t} 1$ \\
\hline AM-1 & 840 & 20 & Medium & $\mathrm{t} 1$ \\
\hline AL-1 & 840 & 20 & Low & $\mathrm{t} 1$ \\
\hline AH-2 & 840 & 40 & High & $\mathrm{t} 2$ \\
\hline AM-2 & 840 & 40 & Medium & $\mathrm{t} 2$ \\
\hline AL-2 & 840 & 40 & Low & $\mathrm{t} 2$ \\
\hline BH-1 & 940 & 20 & High & $\mathrm{t} 1$ \\
\hline BM-1 & 940 & 20 & Medium & $\mathrm{t} 1$ \\
\hline BL-1 & 940 & 20 & Low & $\mathrm{t} 1$ \\
\hline BH-2 & 940 & 40 & High & $\mathrm{t} 2$ \\
\hline BM-2 & 940 & 40 & Medium & $\mathrm{t} 2$ \\
\hline BL-2 & 940 & 40 & Low & $\mathrm{t} 2$ \\
\hline
\end{tabular}

$\mathrm{X}$-ray diffraction analyses (XRD) were carried out with a Philips $\mathrm{X}$-ray diffractometer with $\mathrm{Co}-\mathrm{K}_{\mathrm{a}}$ radiation $\left(\mathrm{K}_{\alpha 1}=1.78901 \AA, 35 \mathrm{kV}, 30 \mathrm{~mA}\right)$, and a Fe filter for suppressing $\mathrm{K}_{\beta}$ radiation. Calibration was performed by means of $\mathrm{Cu}$ radiation $\left(\mathrm{K}_{\alpha 1}=1.5405 \AA 0.0052 \mathrm{q} / \mathrm{s}, 10 \mathrm{~s}\right)$, using Si as standard reference material (Ref. 00-027-1402 quality star (S)). A 2q angle in the range $55^{\circ}$ to $115^{\circ}$ was selected with a scanning speed of $0.52 \mathrm{q} / \mathrm{min}$.

Microstructural characterization was carried out with both an optical microscope (OM) and a scanning electron microscope (SEM) equipped with an Energy Dispersive Spectroscope (EDS). Metallographic preparation was performed according to ASTM E3 [8], by etching the polished metallographic specimens with Nital (2cc HNO3 + 98cc Ethyl alcohol) or Vilella $(5 \mathrm{cc} \mathrm{HCl}+$ 2 gr Picric acid $+100 \mathrm{cc}$ Ethyl alcohol).

Rockwell hardness tests, with a $150 \mathrm{~kg}$ load (HRC), were carried out according to ASTM E18 [9]. Vickers hardness tests with a load of $10 \mathrm{~kg}$, according to ASTM E92 [10], were also carried out on the samples used for the dilatometric analyses.

Tensile tests were performed on a servo-hydraulic machine, equipped with a $300 \mathrm{kN}$ load cell and a clip-on extensometer, according to ASTM E8 [11]. Samples with an initial gauge length $\mathrm{L}_{0}=35 \mathrm{~mm}$ and diameter $\mathrm{d}_{0}=7 \mathrm{~mm}$, were used for the tests; $0.2 \%$ proof strength (YS), ultimate tensile strength (UTS) and elongation to failure $(\mathrm{E} \%)$ were evaluated.
The impact tests were carried out at different temperatures (in the range $-40^{\circ} \mathrm{C}$ to $+20^{\circ} \mathrm{C}$ ), with an impact testing machine, according to ASTM E23 [12], using specimens of $10 \times 10 \times 55 \mathrm{~mm}^{3}$, with a $2 \mathrm{~mm}$ V-notch.

The morphology of the tensile and impact fracture surfaces was investigated by SEM-EDS to elucidate the damage mechanisms involved.

\section{Results and discussion}

\subsection{Dilatometric analysis}

Preliminary dilatometric quenching tests, from different austenitizing temperatures $\left(840^{\circ} \mathrm{C}\right.$ and $\left.940^{\circ} \mathrm{C}\right)$, allowed the critical points for the investigated steel to be determined (Table 3 ). It is worth mentioning that Ms increases by increasing the austenitizing temperature, due to the increasing parent austenite grain size [1]. The critical cooling rate $\left(\mathrm{CR}_{\mathrm{cr}}\right)$ is comprised between 5 and $10^{\circ} \mathrm{C} / \mathrm{min}$

TABLE 3

Critical points for the EN-27MnCrB5 steel obtained by preliminary dilatometric quenching tests. $A c_{1}=$ the temperature at which austenite begins to form during heating, $\mathrm{Ac}_{3}=$ the temperature at which transformation of ferrite to austenite is completed during heating, $\mathrm{T}_{\text {aus }}=$ Austenitization temperature, $\mathrm{CR}_{\mathrm{cr}}=$ critical cooling rate, $\mathrm{M}_{\mathrm{s}}=$ Martensite Start, HV10 = Vickers hardness with $10 \mathrm{~kg}$ load.

\begin{tabular}{|c|c|c|c|c|c|}
\hline \hline $\begin{array}{c}\mathbf{A c}_{\mathbf{1}} \\
{\left[{ }^{\circ} \mathbf{C}\right]}\end{array}$ & $\begin{array}{c}\mathbf{A c}_{\mathbf{3}} \\
{\left[{ }^{\circ} \mathbf{C}\right]}\end{array}$ & $\begin{array}{c}\mathbf{T}_{\text {aus }} \\
{\left[{ }^{\circ} \mathbf{C}\right]}\end{array}$ & $\begin{array}{c}\mathbf{C R}_{\text {cr }} \\
{\left[{ }^{\circ} \mathbf{C} / \mathbf{m i n}\right]}\end{array}$ & $\begin{array}{c}\mathbf{M}_{\mathbf{s}} \\
{\left[{ }^{\circ} \mathbf{C}\right]}\end{array}$ & HV10 \\
\hline \multirow{2}{*}{$738 \pm 2.0$} & \multirow{2}{*}{$799 \pm 2.0$} & $840^{\circ} \mathrm{C}$ & $5-10$ & 336 & $540 \pm 20$ \\
\cline { 3 - 6 } & & $940^{\circ} \mathrm{C}$ & $5-10$ & 359 & $538 \pm 20$ \\
\hline
\end{tabular}

The microstructure of the as-quenched steel $\left(\mathrm{CR}>\mathrm{CR}_{\mathrm{cr}}\right)$ is fully martensitic, the size of laths and packets increases by increasing the prior austenite grain size (Fig. 1).

The dilatometric austempering experiments highlight the expansion related to the austenite to bainite transformation. The curves related to the isothermal portion of heat treatment show that this transformation is fast, taking less than 10 minutes even at the lowest austempering temperature (Low and Very Low in Fig. 2). In this case, the formation martensite precedes that of bainite, as confirmed by a sudden time independent expansion already before starting the isothermal soaking. It is worth noting that the slight contraction shown by these samples is due to an instrumental effect, i.e. the feedback of the induction heating system to the rapid temperature increases accompanying the martensitic transformation. It has also been observed that the total expansion is proportional to the austempering temperature. In the text of this paper, it will be confirmed that, in any case, the austenite transformation is complete after 40 mins, which means that the above results cannot be explained by the different amount of bainite (martensite) forming at different temperatures. A possible explanation could be the different volume expansion related to lower bainite formation, compared to that of upper 

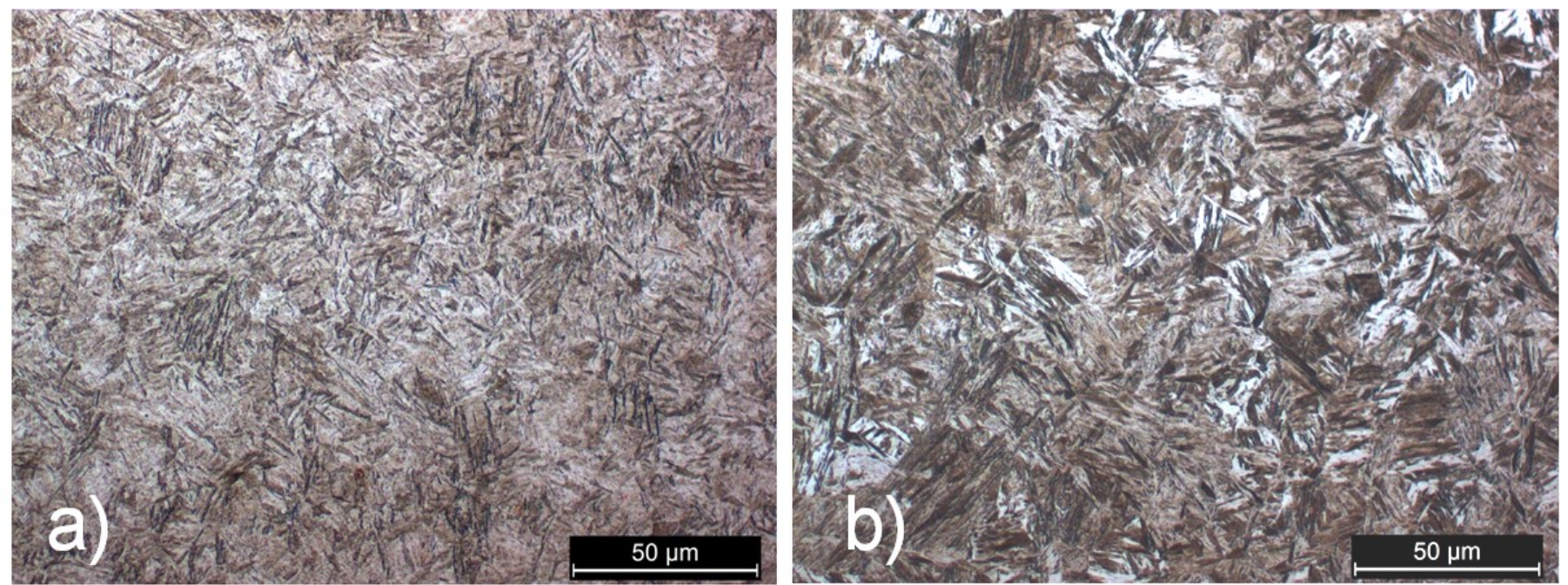

Fig. 1. Microstructure of the as-quenched steel austenitized at (a) $840^{\circ} \mathrm{C}$ and (b) $940^{\circ} \mathrm{C}$ for $30 \mathrm{~min}$
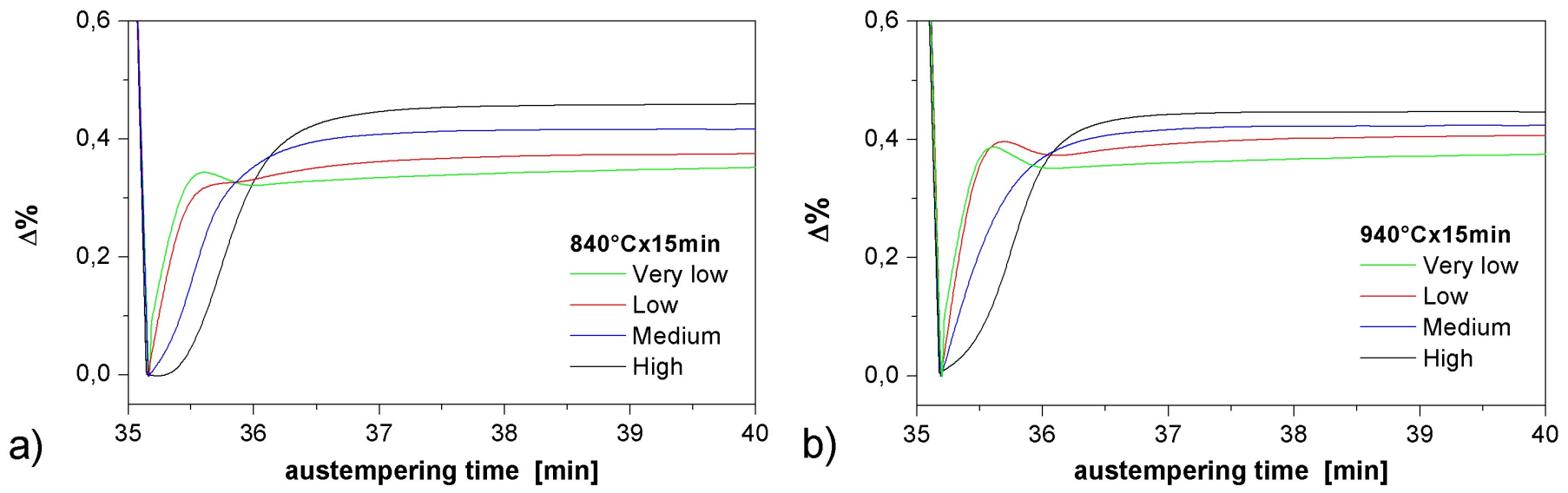

Fig. 2. Dilatometric curves related to the isothermal portion of austempering heat treatment of steel austenitized at: (a) $840^{\circ} \mathrm{C}$ and (b) $940^{\circ} \mathrm{C}$ for $15 \mathrm{~min} . \mathrm{H}=$ High austempering temperature $\left(\mathrm{T}>380^{\circ} \mathrm{C}\right), \mathrm{M}=$ Medium austempering temperature $\left(340<\mathrm{T}<380^{\circ} \mathrm{C}\right), \mathrm{L}=\mathrm{Low}$ austempering temperature $\left(300<\mathrm{T}<340^{\circ} \mathrm{C}\right), \mathrm{VL}=$ Very low austempering temperature $\left(\mathrm{T}<300^{\circ} \mathrm{C}\right)$

bainite. Thus, for example, the coarser cementite particles precipitating at higher temperatures inside the austenite in the interlath regions, show a definitely higher specific volume that that of the finer intralath particles [13]. Of course, this point must be further investigated.

\section{2. $\mathrm{X}$ ray diffraction analysis}

The XRD patterns reported in Fig. 3 are representative of the steel austenitized at $840^{\circ} \mathrm{C}\left(\mathrm{AL}-2\right.$ series) and $940^{\circ} \mathrm{C}(\mathrm{BL}-2$ series) for $40 \mathrm{~min}$ and austempered at a low temperature for $40 \mathrm{~min}$ and austenitized at $840^{\circ} \mathrm{C}$ for $20 \mathrm{~min}$ and austempered at a low temperature (AL-2 series).

While diffraction peaks corresponding to ferrite or martensite $(\mathrm{F} / \mathrm{M}(200), \mathrm{F} / \mathrm{M}(211))$ are visible, the patterns did not highlight the peaks corresponding to austenite $(\gamma(200), \gamma(220))$. This indicates that the amount of retained austenite is lower than $2 \mathrm{wt} \%$, a value that corresponds to instrument sensitivity. Similar results were obtained for all the heat treatment cycles studied.

\subsection{Microstructure}

Representative optical micrographs of the steel subjected to different austempering cycles are reported in Fig. 4. The microstructure of bainite consists of fine plates or laths of ferrite, which grow in clusters called packets or sheaves. Within each packet the plates are parallel and of identical crystallographic orientation, and are usually separated by low angle boundaries or by carbides, while packets are separated by high angle boundaries $[1,6]$.

The microstructure of samples austempered at a high temperature (Fig. 4 a,b) is characterized by the presence of upper bainite, while the samples that underwent a low (Fig. 4 c,d) or medium austempering temperature showed the presence of a mixed microstructure of lower bainite and martensite, with an increased amount of martensite in the samples austempered at a low temperature.

As expected, the samples of the B series have a coarser microstructure compared to the samples of the A series. Even though the bainitic packets are not always well defined, their size increases as both the austenitization temperature and time increase 
646

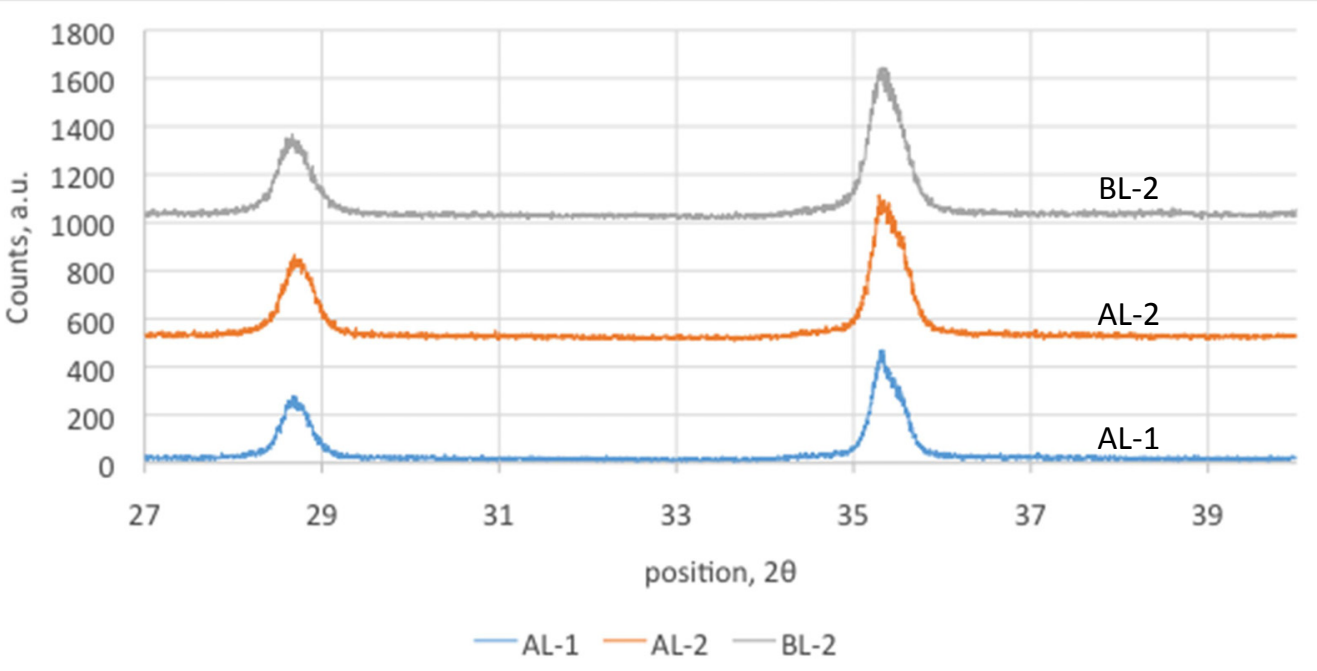

Fig. 3. Representative XRD patterns of samples of AL-1 (BOTTOM), AL-2 and BL-2 (TOP) series
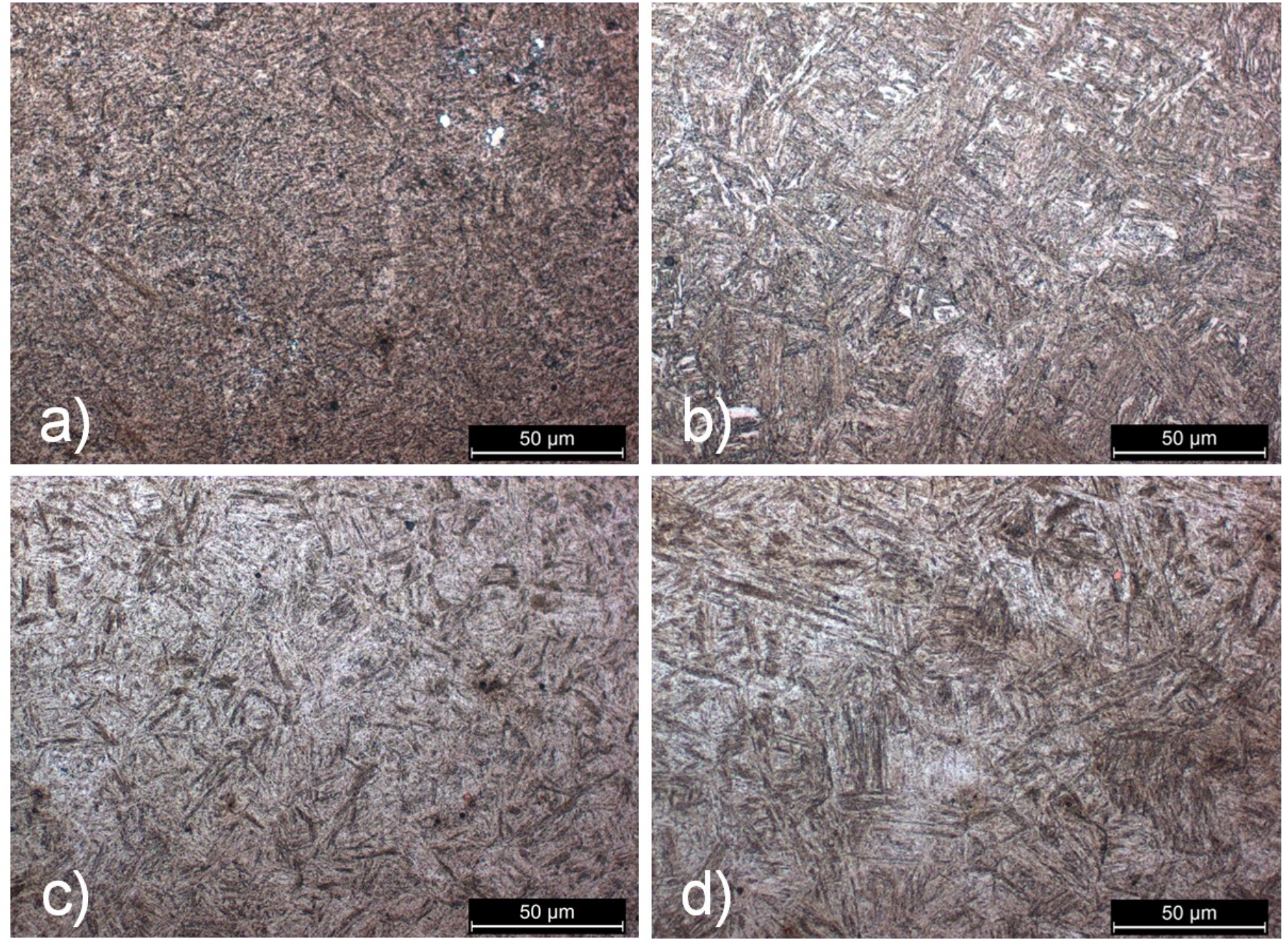

Fig. 4. Representative OM images of the steel after different austempering cycles: (a) AH-1, (b) BH-1, (c) AL-1, (d) BL-1

while, under the same austenitization conditions, it decreases as the austempering temperature decreases. According to $[1,14]$, in fact, the bainitic packets develop inside the austenite grains and their size decreases as the prior austenitic grains decrease until, for very fine austenitic grains, each grain transforms into a packet. At low austempering temperatures the simultaneous presence of bainite and martensite packets, developing in the same austenite grains, magnifies the size reduction of the packet.

SEM metallographic analyses at relatively low magnification (Fig. 5 a,b) allow the bainitic and martensitic regions to be 

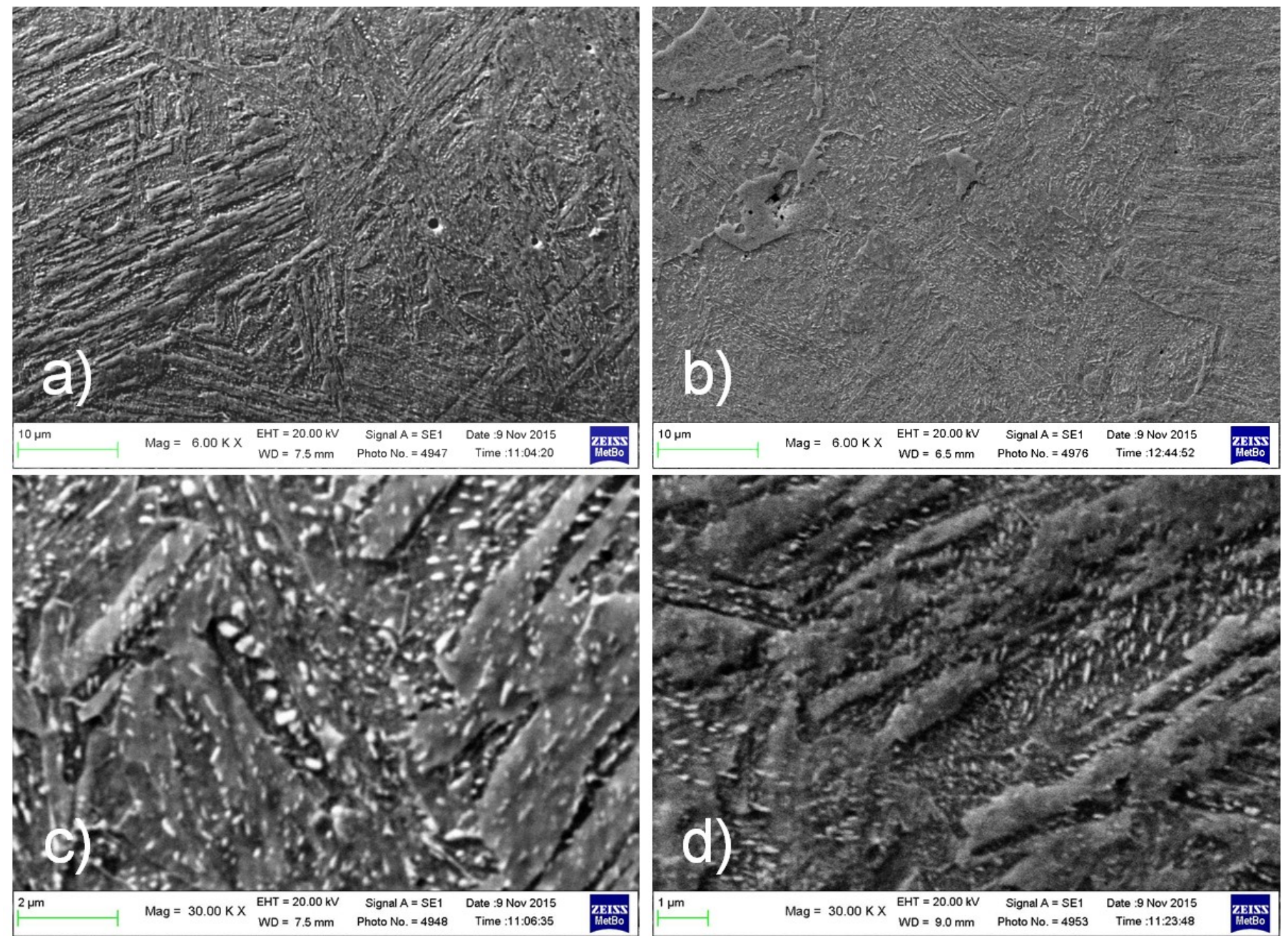

Fig. 5. Representative SEM images of the steel after different austempering cycles: (a) BM-1 (b) AM-1, (c) BM-1, (d) BL-1

better resolved, the first ones being characterized by a rougher aspect and presence of coarser carbides, with respect to the second ones

At higher magnification (Fig. 5 c,d), the size and morphology of the ferrite plates and coarser carbides can be clearly seen, while finer precipitates are not resolved. Lower austempering temperatures lead to finer ferrite plates and carbides. Moreover, while at a high austempering temperature carbides mainly develop along the ferrite plates, at a medium or low austempering temperature the cementite particles are extremely fine and often do not have a preferential orientation, thus having a more homogenous particle distribution. As reported in [1], the cementite particles in lower bainite frequently precipitate in one variant of the orientation relationship, such that they form a parallel array at about $60^{\circ}$ to the axis of the bainite plate, but a few fine cementite particles can also precipitate between the ferrite plates.

Moreover, as also highlighted by OM analysis, the samples austenitized at a high temperature (B series) exhibit a coarser microstructure with respect to the samples austenitized at a low temperature (A seris).

SEM analyses, however, were not able to highlight the effect of different austempering times, even though this parameter had a clear effect on impact toughness, as reported in Sect. 3.4.2.

\subsection{Mechanical properties}

\subsubsection{Hardness and tensile tests}

The results of hardness and tensile tests, reported in Fig. 6, allow the main observations to be drawn.

At the same austenitization temperature, a reduction of the austempering temperature leads to an increase in hardness and tensile strength. Samples austempered at a low temperature (ALand BL-series) displayed HRC, YS and UTS about 20\% higher than samples austempered at a medium temperature (AM- and BM- series), and about $40 \%$ higher with respect to samples austempered at a high temperature (AH- and $\mathrm{BH}$-series). Moreover: 1. By decreasing the austenitization temperatures, under the same austempering conditions, the strength increases. Series A samples displayed YS and UTS values about 5-10\% higher than the samples belonging to the B series.

2. By decreasing the austenitization and austempering holding time, under the same austenitization and austempering temperatures, the strength slightly increases.

These results are in agreement with the microstructural modification developed in the steel subjected to different austempering cycles. 

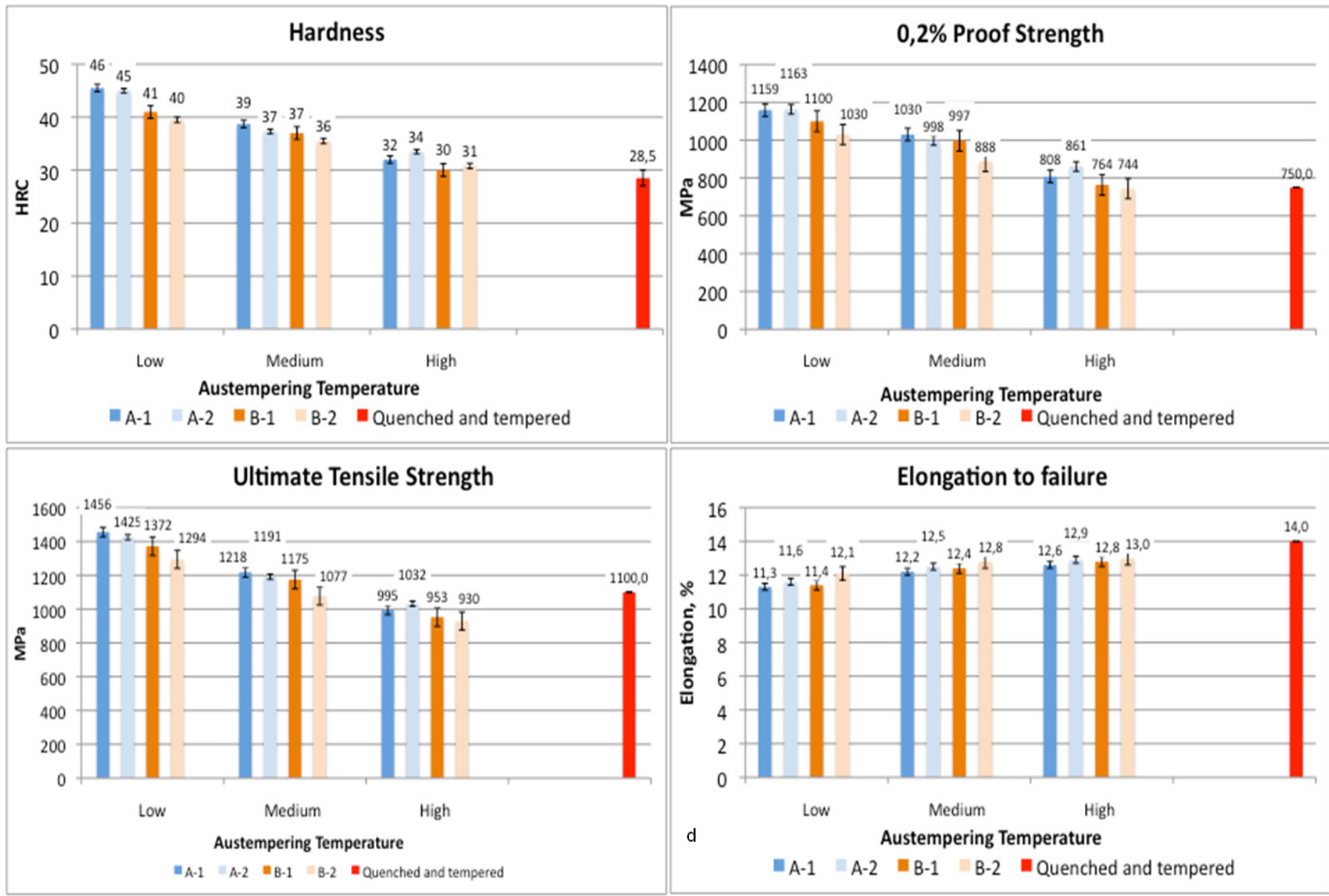

Fig. 6. Mechanical properties of the austempered steel: (a) hardness (HRC), (b) proof strength (YS) (c) ultimate tensile strength (UTS), (d) elongation to failure (E\%). Mechanical properties of Q\&T steel are derived from [16]

A low austempering temperature leads to the development of a mixed bainitic-martensitic microstructure, where martensite clearly significantly enhances the steel strength due to its superior strength with respect to bainite [4]. Moreover, the development of both martensite and bainite from the prior austenite grains leads to smaller packets of martensite and bainite, and induces plastic constraints in the bainite [15]. The reduction in the packet size of both martensite and bainite, of which the boundaries act as high angle boundaries, and the increase in the dislocation density in bainite lead to a further increase in steel strength $[4,6]$.

Moreover, low austempering temperature induces the formation of:

1. finer carbides in the ferrite or eventually in the inter-plate position that can hinder dislocation movement, leading to an increase in both toughness and strength.

2. finer ferrite laths, which acting as low angle boundaries, can hinder dislocations movement and increase material strength.

A lower austenitization temperature, shorter austenitization and austempering holding times also lead to finer microstructures in terms of both bainite and ferrite laths, carbides, martensite and bainite packets, with a consequent increase in strength.

As expected, elongation to failure follows a reverse trend with respect to YS and UTS. However, the differences in E\% among the differently treated samples are slight, and the ductility of austempered samples is close to that of Q\&T steel.

The fracture surface analysis (Fig. 7) confirms the tensile data, and highlights the presence of a typical ductile morphology in all the samples, irrespectively of the heat treatment parameters, with large dimples surrounded by small dimples due to finer carbides.

\subsubsection{Impact tests}

The results of impact tests at room temperature and at low temperature are reported in Fig. 8. The data clearly highlight the synergic effect of austempering and austenitization temperatures as well as the holding time on impact toughness.

In particular, impact toughness decrases:

1. By increasing the austenitization temperature, for all the austempering temperatures and holding times, both at room temperature and sub-zero testing temperatures. The samples belonging to the $\mathrm{B}$ series have an impact toughness about $20 \%$ lower than the corresponding A series samples.

2. By increasing the austempering temperature. The energy absorbed by the samples austempered at a high temperature (AH- and $\mathrm{BH}-$ series) is $30-40 \%$ of that absorbed by the 
samples austempered at a low temperature (AL- and BLseries). At room temperature, the impact toughness of the samples austempered at a low and medium temperature (AM- and BM-series) is comparable.

3. By increasing the austenitization and holding time, the samples of the A-2 and B-2 series have an impact tough- ness $20-40 \%$ lower than that of the samples of the A-1 and B-1series.

Moreover, it is worth noting that the samples austempered at a low and medium temperature displayed higher impact toughness compared to Q\&T toughness [6].
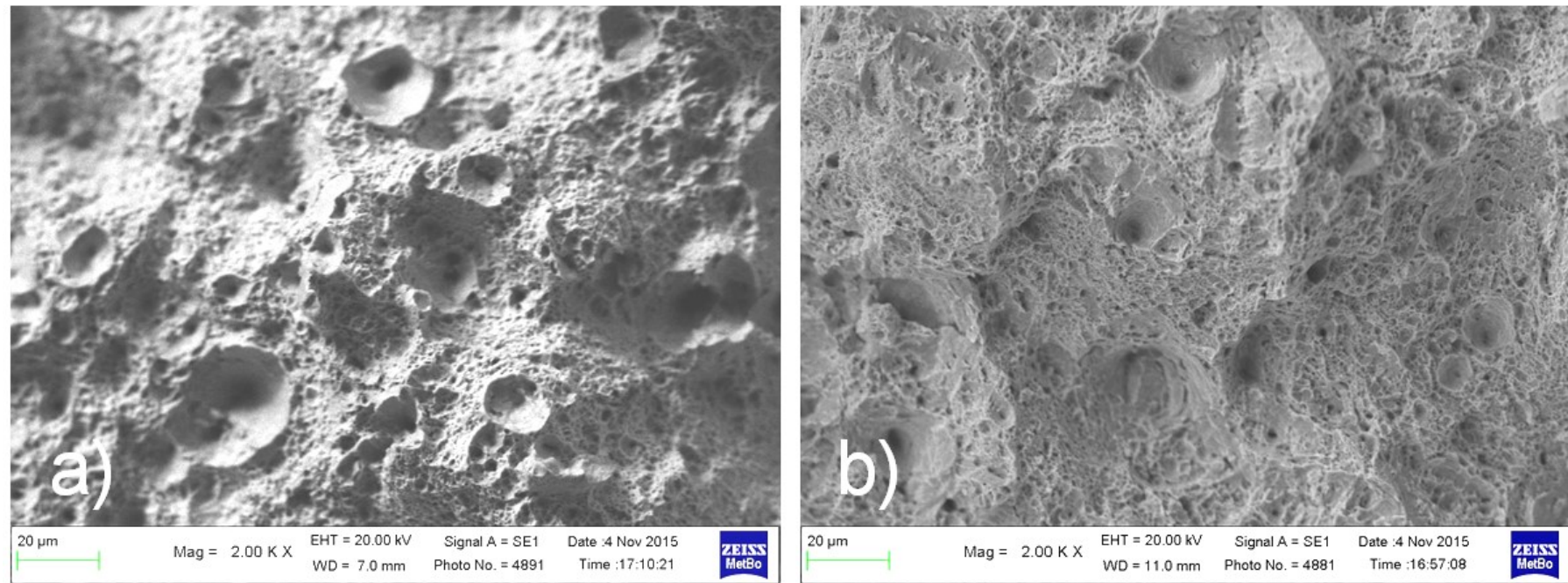

Fig. 7. SEM micrographs of the fracture surfaces of tensile samples tested at room temperature: (a) AL-1, (b) BH-1 series
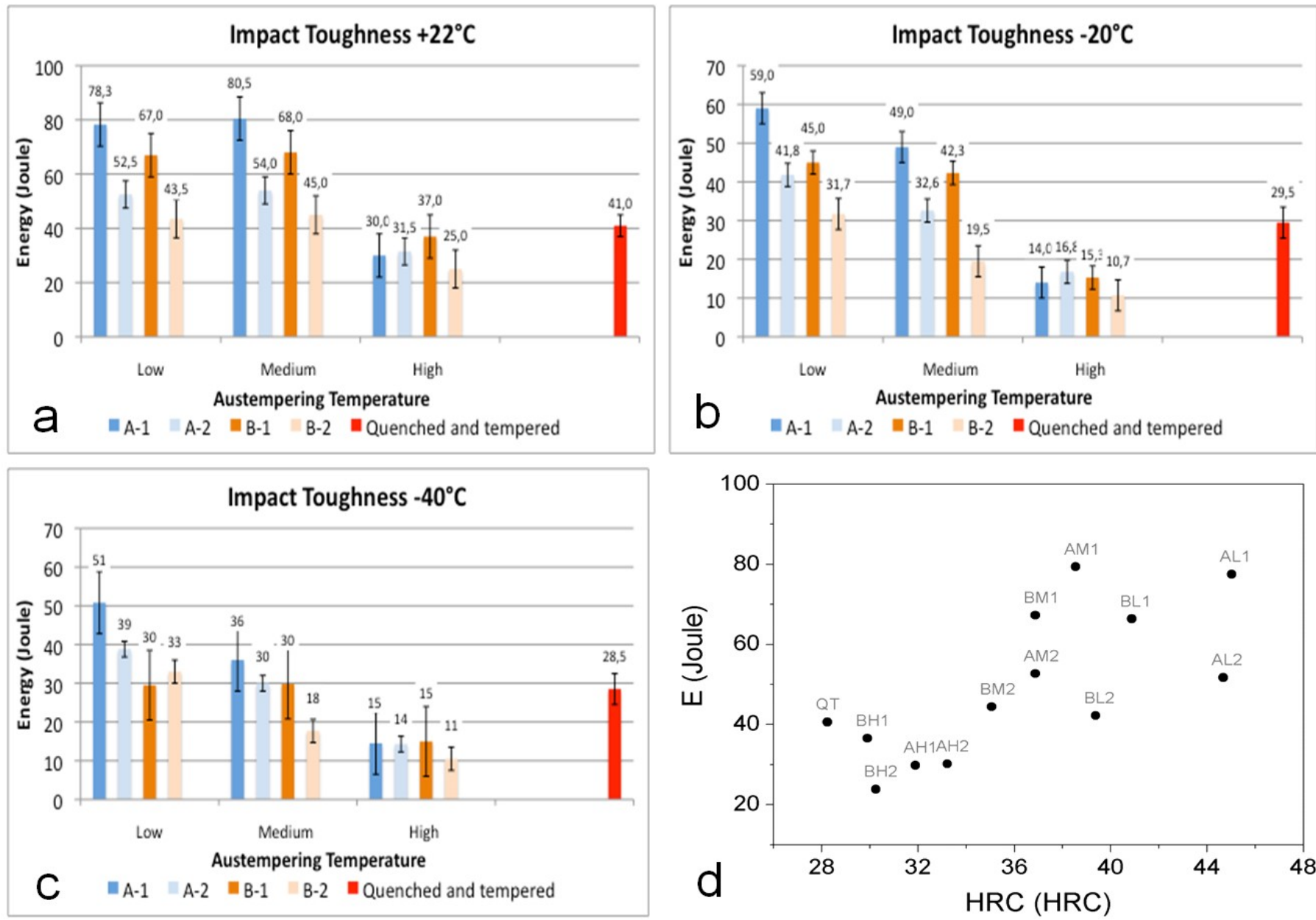

Fig. 8. Results of impact toughness tests of the austempered steel: (a) tests at $22^{\circ} \mathrm{C}$, (b) tests at $-20^{\circ} \mathrm{C}$ (c), tests at $-40^{\circ} \mathrm{C}$, (d) relationship between $\mathrm{HRC}$ and impact toughness for samples testedat $22^{\circ} \mathrm{C}$ 


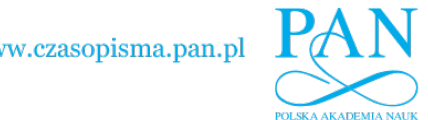

It is widely known that finer carbide and more uniform carbide distribution can increase bainite impact toughness, because coarser carbides can act as cleavage crack nucleation sites $[1,4,17]$. This assessment is confirmed by the impact test results that highlight the negative effect of a longer holding time at a higher austempering temperature on impact toughness due to significant carbide growth.

However, the higher impact toughness of the samples with a mixed microstructure, compared to samples with only an upper bainitic microstructure, is mainly due to the presence of small martensite and bainite packets, which appear to be the microstructural unit that controls the cleavage resistance of bainitic low carbon steels $[6,7]$. When a cleavage crack nucleates and propagates, the boundaries between the bainitic packets, or between the martensitic and bainitic packets can blunt the crack tip, stop crack propagation and/or change its propagating direction, thus increasing the energy needed for its growth $[1,14]$. The proportion of boundaries between the packet increases with the reduction in packet size, therefore the simultaneous presence of bainitic and martensitic packets that develop from austenite grains reduces their size and increases the impact toughness of the steel.
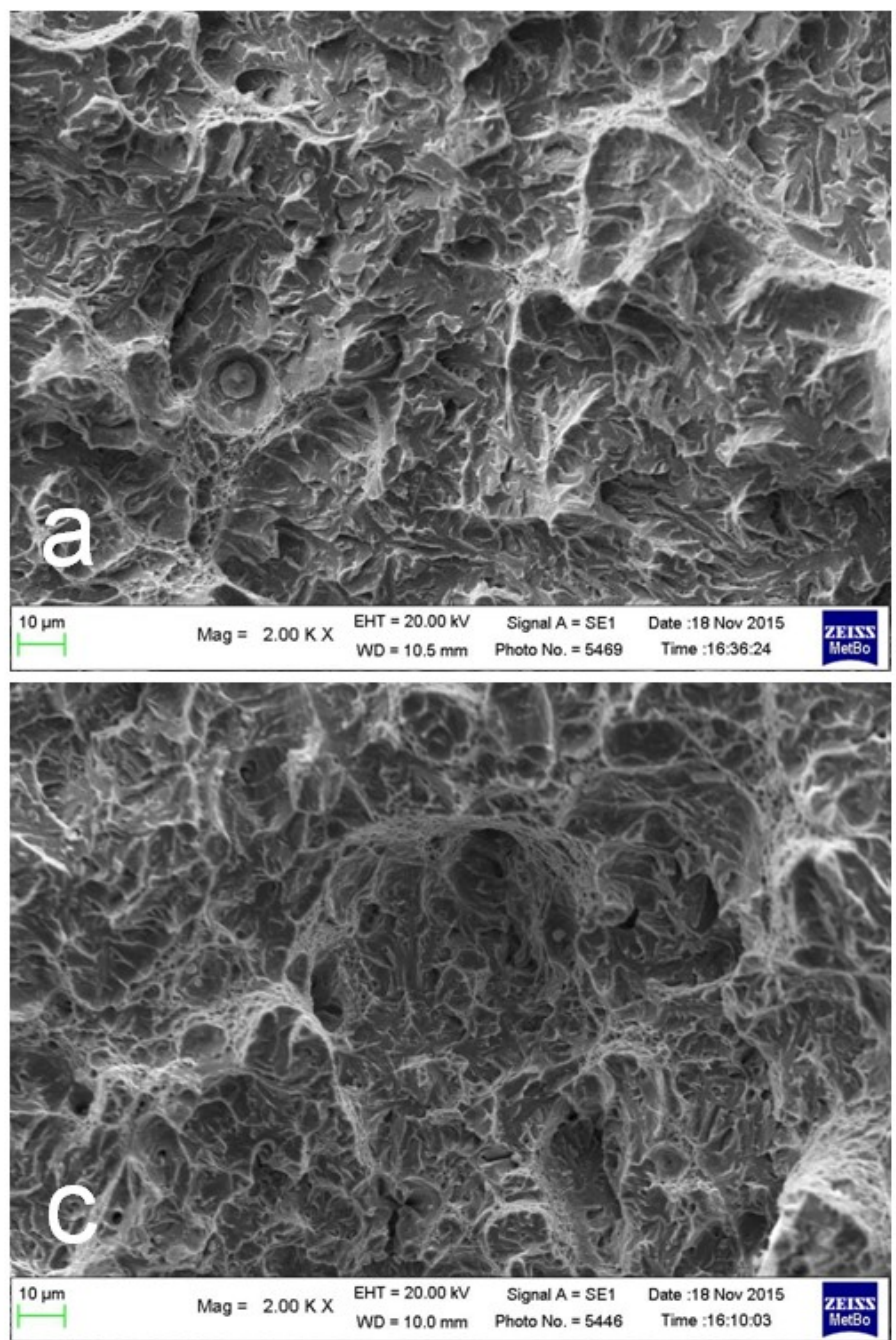

Fig. 9. Fracture surfaces of impact samples tested at room temperature: (a) AM-1, (b) BM-2, (c) AL-1, (d)BL-2
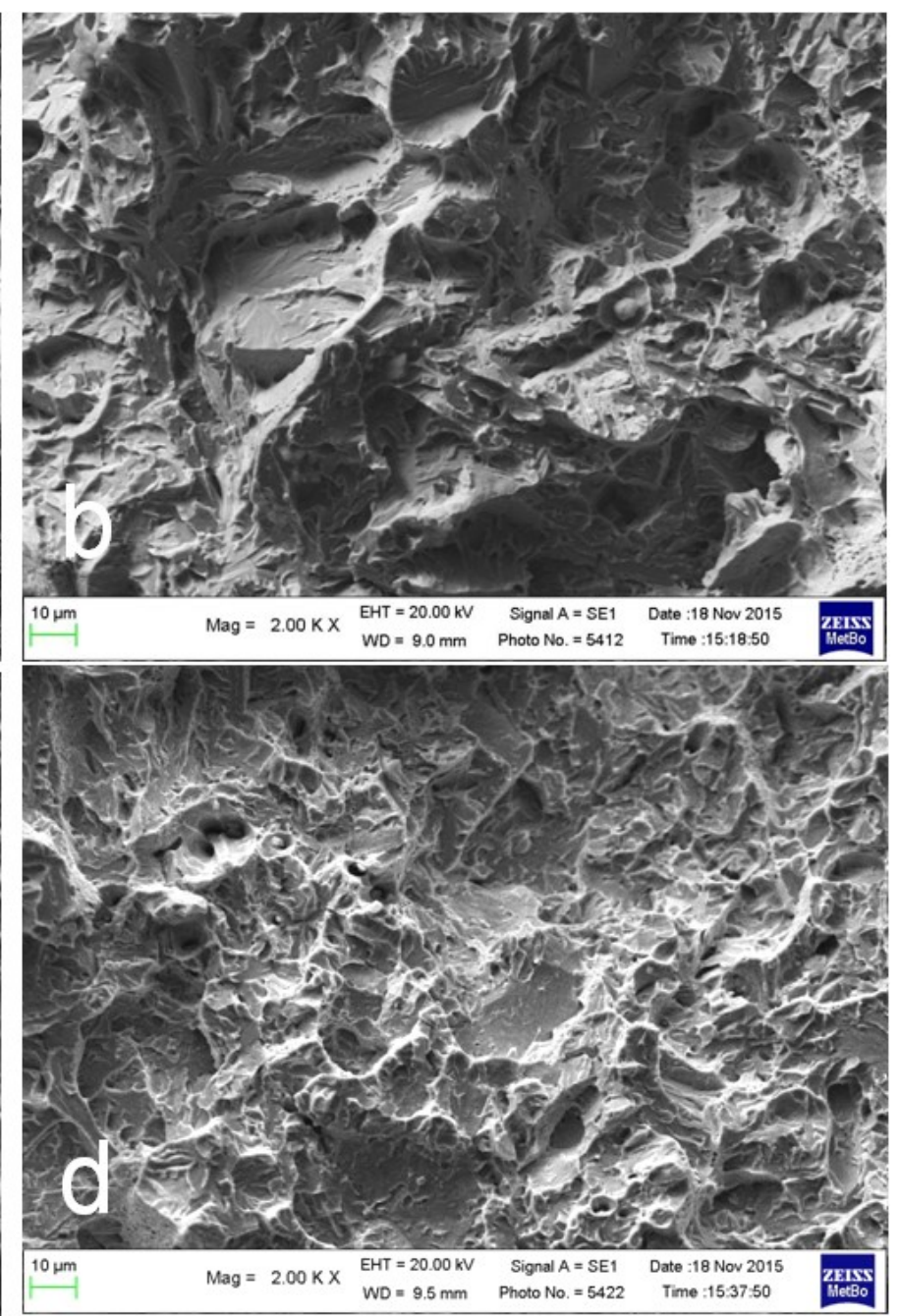

This also explains the importance of the austenitization temperature, which strongly influences the prior austenite grain size. A lower austenitization temperature leads to finer austenite grains and consequently to finer packets.

Representative fracture surfaces of impact samples are reported in Fig. 9. The fracture surfaces of different specimens are characterized by a quasi-cleavage fracture in which both cleavage planes and ductile dimples are present. Obviously, the amount of cleavage fracture increases in samples tested at a low temperature and, for the same testing temperature, it is more pronounced in those with lower impact toughness.

The samples with a mixed microstructure show the presence (with different amounts) of both small ductile bands and dimples at the boundaries of the small cleavage facets.

The samples with upper bainite, instead, show large cleavage facets and, consequently, a limited presence of ductile bands and dimples, in agreement with general expectation.

Cleavage facet size, apparently correlated with the width of fracture. Smaller packets induce an increase in plastic deformation and consequently an increase in energy dissipation during crack propagation [17], in agreement with the impact test data. the packets, therefore influences the amount of ductile and brittle 


\section{4 . Conclusions}

The results of the present study highlight that austempering can effectivelly replace the Q\&T treatment in EN 27MnCrB5-2 steel. The best mechanical behaviour, in terms of strength and toughness, is achieved when the austempering treatment leads to a mixed microstructure of lower bainite and martensite.

The microstructure is influenced by both austenitization, austempering and temperature. While the austenitization temperature affects the size of the bainitic laths, as well as the bainitic and martensitic packets, the austempering temperature has an effect on the morphology of the bainite (upper or lower), the packet size, and the amount of martensite.

Lower austenitization temperature, shorter austenitization and austempering holding times lead to finer mixed microstructures, with a consequent increase in strength and only a slight reduction in elongation to failure.

The presence of a mixed microstructure in the austempered steel with small martensitic and bainitic packets, which appear to be the microstructural unit controlling the cleavage resistance of low carbon bainitic steels, leads to an impact toughness higher than that of Q\&T steel.

Impact toughness vs hardness highlights the positive toughening effect of a mixed martensite/lower bainite microstructure, both at room temperature and low temperatures.

\section{REFERENCES}

[1] H.K.D.L. Bhadeshia: Bainite in Steels: Transformation, Microstructure and Properties, 2001, IOM Communications Ltd., London.
[2] J. Tartaglia, K. Lazzari, G. Hui , K. Hayrynen: Met. Trans. A 9A, 559-576 (2008).

[3] Kangying Zhua Mat. Sci. Eng. A 57, 6614-6619 (2010).

[4] K. Abbaszadeh, H. Saghafian, S. Kheirandish, Sci. Technol. 28 (4), 336-342 (2012).

[5] Y. Tomita: Metall. Mater. rans. A, 4, 2387-2393 (1983).

[6] L. Rancel, M. Gmez, S. F. Medina, I. Gutierrez, Mat. Sci. Eng. A 30, 21-27 (2011).

[7] A. Di Schino, C. Guarnaschelli, Mater. Lett. 3, 1968-1972 (2009).

[8] ASTM E3-01, Standard Practice for Preparation of Metallographic Specimens, ASTM International, West Conshohocken, PA, 2001.

[9] ASTM E18-16, Standard Test Methods for Rockwell Hardness of Metallic Materials, ASTM International, West Conshohocken, PA, 2016.

[10] ASTM E92-16, Standard Test Methods for Vickers Hardness and Knoop Hardness of Metallic Materials, ASTM International, West Conshohocken, PA, 2016.

[11] ASTM E8 / E8M-15a, Standard Test Methods for Tension Testing of Metallic Materials, ASTM International, West Conshohocken, PA, 2015.

[12] ASTM E23-12c, Standard Test Methods for Notched Bar Impact Testing of Metallic Materials, ASTM International, West Conshohockn, PA, 2012.

[13] J. Pacyna, Arch Metall Mater 59 (4), 1679-1683 (2014).

[14] J. Nohava, P. Hausild, M. Karlik, P. Bompard, Mater. Charact. 49, 211-217 (2002)

[15] C.H. Young, H.K.D.L Bhadeshia, Mater. Sci. Technol. 10, 209-214 (1994.

[16] www.keytometals.com

[17] H. Song, C.M. Li, L. Lan, D. Zhao, J. Iron Steeles Int. 2 (8), 72-77 (2013). 